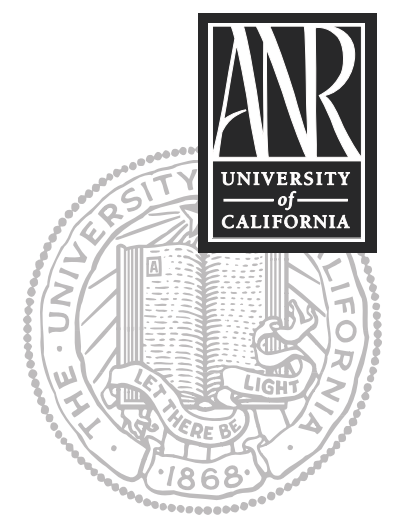

UNIVERSITY OF CALIFORNIA

Division of Agriculture and Natural Resources http://anrcatalog.ucdavis.edu

\title{
Growing Prunes (Dried Plums) in California: An Overview
}

MAXWELL V. NORTON, UC Cooperative Extension Farm Advisor, Merced County; and WILLIAM H. KRUEGER, UCCE Farm Advisor, Glenn County.

California produces 99 percent of the nation's prunes and 70 percent of the world's prune crop. Other major prune-producing countries are France, Chile, and Argentina. Almost all of California's prune acreage is located in the Central Valley-about 80 percent of it in the Sacramento Valley and 20 percent in the San Joaquin Valley. As of 2005, the ten counties with the most acreage are (in descending order) Sutter, Butte, Yuba, Tehama, Glenn, Tulare, Fresno, Merced, Yolo, and Colusa.

\section{PLANNING THE ORCHARD}

Potential for Profit. The Central Valley's climate allows for good production of highquality prunes. Spring frost during bloom may be a hazard in some areas. Profitable prune growing is based on the grower's ability to consistently produce moderate crops of large-sized prunes. Fruit size determines the price paid, and large crops generally consist of small fruit that are less valued and more costly to process; also, a large crop is usually followed the next season by a smaller crop. Growers can prune and mechanically thin to control crop load and promote larger fruit with the goal of matching the crop load to the sizing potential of the orchard.

A mature, properly developed, well-managed, mature orchard on good soil can produce 12 to 15 green (not dried) tons per acre. Dry-away ratios (the ratio of green fruit weight to dry fruit weight) range from 2.8 to 3.5. As an example, a harvest of 15 tons with a dry-away ratio of 3.5 would yield 4.3 tons per acre when dry. The undersized fruit and trash percentage depends upon management practices, but a good rule of thumb is to put it at 3.25 percent, which would bring the saleable tonnage from this example to 4.15 dry tons per acre. The state average annual gross dry yield for 1995-2004 was 2.01 dry tons per acre. This includes marginal and old acreage.

From 1995 to 2004, average grower returns from saleable tonnage ranged from a high of $\$ 1,469$ per ton to a low of $\$ 739$. Average return for the period was $\$ 905$ per ton. The price to the grower will depend upon dry fruit size and quality as well as market dynamics.

Production Costs. University of California Cooperative Extension offices in prune-producing counties have cost studies available that show generalized prune production costs for their area. UC cost studies for most commercial crops are also available on the Internet at http://coststudies.ucdavis.edu. Many financial institutions can help with cost analysis. A major cost of production is processing (dehydrating, sorting, handling, and hauling). Because processing charges are based on green tonnage and growers are paid for saleable dry tonnage, a grower is paid more to produce large, defect-free fruit with low dry-away ratios.

Climate. Prunes require adequate winter chilling (approximately 800 to 1,100 hours of temperatures below $45^{\circ} \mathrm{F}$ ) for normal flowering and fruit set. Hot, dry conditions during bloom can result in a shortened bloom period and reduced fruit set. Wet weather during bloom can favor blossom and fruit disease. For best yield and quality, a warm, dry growing season is most desirable. Spring frost is less of a problem with prunes than with earlier-blooming crops such as almonds, but an orchard in a frost-prone area often requires additional expenses for frost protection. Prunes bloom around early March in southern locations and mid-March in northern locations. 
Suitable Soils. Prunes are most productive on well-drained, uniform, medium and moderately fine-textured loamy soils. In reality, they are planted on a wide variety of soils, from quite sandy soils to fairly heavy clays. Most prune rootstocks tolerate wet soil conditions better than many rootstocks for other tree crops. Although county soil surveys provide excellent information on soils, they may not show adequate detail. Use a backhoe to dig several holes on the prospective property in areas where you might expect to find differences in soil type. Look for anything that might restrict water movement and root growth, such as clay pans, hardpans, silt pans, stratification, and high water tables. Soil chemical analysis can reveal problems with $\mathrm{pH}$, salinity, and boron, sodium, and chloride toxicity. Correcting soil problems before you plant is the more effective, less expensive option. If you are not familiar with soil evaluation techniques, contact your UC Cooperative Extension office for assistance.

Irrigation. Like many other tree crops, mature prune orchards with vegetation between the rows will evapotranspire about 40 to 42 acre-inches of water per year. Peak water use in California's Central Valley is about 0.25 to 0.3 inch per day. If you allow for irrigation system efficiency, periods of exceptionally hot, windy weather, and interrupted water supplies, the system should still be designed to deliver at least 0.4 inch per day.

The specific type of irrigation system is not as important as how well it is designed and how well it is managed. The system should uniformly distribute adequate water to each tree. Which system you choose will depend on the cost of water, the type and depth of soil, the amount of land leveling needed, and any special management problems that are present in the orchard.

Planting trees on a berm (a raised area of soil along a tree row) and flooding the middles is common practice and usually (on already leveled land) involves a low initial cost. Solid-set sprinklers can also be used for frost control. Low-volume (drip and microsprinkler) irrigation systems are becoming more common and seem particularly well suited to marginal soils. A low-volume irrigation system can also be used to deliver potassium and other fertilizers to trees.

Varieties. Prunes are varieties of European plum (Prunus domestica). While all prunes are plums, not all plums can be dried into prunes. French has good yields of high-quality fruit that is fairly easy to pit, with dry-away ratios in the general range of 3.0 to 3.5. This strong, vigorous tree has a moderate tendency toward alternate bearing when crop size is not controlled by pruning or thinning. Most commercial prune varieties are self-fertile and do not need pollenizer varieties (as do almonds), but bees may be used to improve set.

Several new varieties have been introduced recently by the University of California. For information on these new varieties, contact your local UC Cooperative Extension Farm Advisor.

\section{ESTABLISHING THE ORCHARD}

Good planning is essential for efficient operation and ultimate profitability. Before planting, you need to set up an irrigation system, level the land to promote uniform water distribution, deep till, rip or backhoe to destroy or mix impervious layers in the soil profile, fumigate (if necessary), and choose the proper variety and rootstock.

Prune trees are spaced 16 to 20 feet apart to provide for efficient use of large mechanical harvesters. Trees can be planted closer together, but will require modified harvesting equipment. The trees may be planted in square, rectangle, quincunx, or hexagonal configurations. Higher-density plantings may require the use of modified equipment. 
Select good-quality trees from a reputable nursery. Select vigorous trees $1 / 2$ to $5 / 8$ inch in diameter with good root systems and smooth graft unions. To ensure good selection, order early. Late orders are often filled from other nurseries and tree quality may suffer. Adequately trained crews must carefully plant the new trees. Experienced personnel should be used to survey, lay out, and mark the new orchard.

Rootstocks. Three plum-type rootstocks are commonly used with prunes. Which one you select will depend on soil type and any site-related growing problems.

Myrobalan 29C is widely used. It has excellent vigor, is vegetatively propagated, resistant to root knot nematode, mildly resistant to Armillaria root rot and to crown gall, and susceptible to bacterial canker. Myrobalan 29C is shallow-rooted and has poor anchorage. It is also susceptible to brownline virus.

Mariana 2624 is vigorous, vegetatively propagated, immune to root knot nematode, moderately resistant to Armillaria root rot and to crown gall, and highly susceptible to bacterial canker. Brownline virus does not affect it. Mariana 2624 has poorer anchorage than Myrobalan 29C and a greater tendency toward root suckering. Mariana 2624 is also widely used.

Myrobalan seedling rootstocks are propagated from seeds and are genetically more variable than vegetatively propagated types. Myrobalan seedlings are susceptible to root knot nematodes, bacterial canker, Armillaria root rot, and crown gall. Their main advantage is that they have better anchorage.

Other rootstocks such as Lovell peach, Nemaguard peach, and almond are used in rare instances to overcome special problems. Before choosing a rootstock, consult your local UC Cooperative Extension Farm Advisor.

Equipment. Equipment commonly needed for a 40-acre orchard might include a 40 to 60 horsepower wheel tractor; a 9-foot offset wheel disc or an 8-foot mower; a 3point push scraper; a weed sprayer; a furrower (if you furrow-irrigate); 3-point forks for moving bins; a utility wagon; a hydraulic pull scraper; an orchard sprayer; a harvester; a forklift; and a bin carrier. A custom operator can provide the last five pieces of equipment or you can rent them.

\section{MANAGING THE ORCHARD}

Training and Pruning. Train prune trees to provide a strong, open framework capable of supporting a large crop. Economic yields usually occur in the fourth or fifth year. For detailed information on training and pruning, please read the chapter on pruning in Prune Orchard Management (David E. Ramos, 1981 [UC Agricultural Sciences Publication 3269, out of print but available in some libraries, and an updated edition is in the works]).

As is the case with peaches and almonds, mature prune trees must be pruned to maintain consistent, uniform yields and good size and to reduce alternate bearing. A variety of pruning systems are in use. You can discuss them with a UC Cooperative Extension Farm Advisor.

Orchard Floor Management. Mechanical harvesting requires a smooth, firm orchard floor. Common management systems include complete cultivation, cultivation of the middles, spraying the tree strips, mowing of the middles with tree strip weed control, and mowing in both directions.

Managing Bees. Whether you will need bees for any given orchard depends upon its history and surrounding conditions. We do know that by increasing the number of bees in the orchard you can increase fruit set. We do not know whether there is always an economic benefit from doing so. If the orchard block historically sets good crops, the addition of bees probably is not needed and may only increase your fruit thinning costs later on. If the orchard manager is not satisfied with the set, he or she may want to rent one-half to one hive per acre to increase pollination. 
Fertilizing. Generally, 100 pounds of actual nitrogen per acre is applied annually to support heavy production. Prune trees are heavy users of potassium and often become deficient, resulting in sunburn, shoot and twig dieback, predisposition to canker diseases, and crop reduction. Potassium deficiency is corrected with four to six foliar sprays of potassium nitrate, massive soil applications of potassium sulfate every 3 to 5 years, or annual soil application of lower, maintenance rates. Potassium chloride application is an option, but it carries the risk of chloride injury. Occasional zinc deficiencies can be corrected with foliar applications. July tissue analysis is commonly used to determine the trees' nutritional status.

Developing the Crop. The most profitable French prune orchards are those that regularly produce moderate crops of large-sized dried prunes. Excessive cropping results in small and sometimes worthless dried fruit. Adequate pruning will help improve fruit size and drying ratios and keep alternate bearing under control. Mechanical fruit thinning with the same equipment used for harvest can improve fruit size and minimize the potential for alternate bearing.

\section{PEST MANAGEMENT}

Major insect pests that may require treatment include the mealy plum aphid (MPA), leaf curl plum aphid (LCPA), peach twig borer (PTB), and San Jose scale (SJS). Other secondary pests that may occasionally require treatment include mites, bud moths, codling moth, omnivorous and oblique-banded leafrollers, orange tortrix, leaf-eating caterpillars, green fruit worm, and a variety of wood borers.

The most common spring diseases are blossom brown rot (which can be severe with warm, wet weather during bloom) and russet scab. Both are commonly treated with fungicides during bloom. Unharvested fruit mummies are often removed to reduce brown rot innoculum.

Prune rust is a mid-season disease that can cause early defoliation and often requires treatment during the growing season. Other less-common diseases that can damage fruit or trees are Armillaria root rot, Phytophthora crown and root rot, brownline virus, bacterial canker, Ceratocystis canker, crown gall, and Cytospora canker.

Nematodes (microscopic worms that feed in and on the prune tree's roots) are associated with sandy soils and locations where fruit and nut trees have previously been grown. The best control measures for nematodes are thorough cleaning up of old roots, backhoeing, and preplant fumigation.

Weed management measures for prunes are similar to those used for other tree crops. Common management systems usually include chemical control around the base of the tree or along the berm and discing or mowing in the centers.

A pest control program for prunes may include the following:

\begin{tabular}{|l|l|l|}
\hline Timing & Materials & Pests controlled \\
\hline Dormant & Herbicides & Weeds \\
\hline Fall or dormant & Insecticides with or without oil & Aphids, PTB, SJS \\
\hline Green bud & Fungicides & Brown rot \\
\hline Full bloom & Fungicides & Brown rot and russet scab \\
\hline Spring, summer & $\begin{array}{l}\text { Fungicide } \\
\text { Foliar nutrients }\end{array}$ & $\begin{array}{l}\text { Rust } \\
\text { Nutritional deficiencies }\end{array}$ \\
\hline Spring and summer & $\begin{array}{l}\text { An additional fungicide, insecticide or } \\
\text { miticide is often needed, depending } \\
\text { upon which problems develop. }\end{array}$ & \\
\hline Fall & Foliar nutrients, zinc & Nutritional deficiencies \\
\hline
\end{tabular}


Concerns related to surface water contamination from dormant spray runoff have led to the development and implementation of environmentally responsible pest management alternatives. When dormant sprays are eliminated, aphids often emerge as the primary pest. San Jose scale (SJS) populations will usually fall under biological control and PTB has seldom been known to cause economic damage. Seasonal Guide to Environmentally Responsible Pest Management Practices in Prunes (UC ANR Publication 21624) is available from your local UC Cooperative Extension office or online at http://anrcatalog.ucdavis.edu. For more information, obtain a copy of Prune: UC IPM Pest Management Guidelines from your local UC Cooperative Extension office or the UC IPM website (http://ipm.ucdavis.edu).

\section{HARVESTING, DRYING, AND PROCESSING}

Optimal harvest timing is critical to a successful crop. When fruit flesh softens to 3 to 4 pounds' pressure (as determined with a firmness tester), harvest should begin. At 3 to 4 pounds, fruit reach their maximum sugar content and the drying ratio will be as low as possible for that fruit. Most prune growers do not have enough equipment to harvest all of their acreage at optimal maturity, so they initiate harvest slightly before optimal maturity, hoping to harvest the bulk of the crop "on time." The early fruit will be slightly underripe and some late fruit will drop. In very heavy years, the drier may set harvest quotas that growers must abide by. In-field mechanical sorting of small, less-valuable fruit to avoid costly processing can reduce your dehydrating costs.

Today, all California prunes are dried in gas dehydrators. Drying has become one of the most expensive operations in prune production. Typically, prunes arrive at the drying yard in 1,000 lb bins. Next, the fruit is washed, mechanically loaded onto trays, stacked, and moved into drying tunnels. Fruit is usually dried in 18 to 22 hours.

The dried prunes are then stored dry until processing, which includes rehydration and pitting or cooking to make juice. Before you plant a prune orchard, determine whether there is sufficient dehydration capacity in the area to handle your projected tonnage.

\section{MARKETING}

Prunes are sold through several channels. Some are more risky and require active participation by the grower. The industry is served by several private packers that purchase fruit. Lists of handlers who process and sell prunes are available from the Dried Plum Marketing Board and the Prune Bargaining Association. Talk to as many companies as possible and ask other growers about their reliability and reputation. You should have a lawyer review any contract, detailing the responsibilities and protections of all the parties involved.

The industry is also served by Sunsweet Growers, a grower-owned, grower-operated cooperative that handles prunes, apricots, and cranberries. The cooperative processes, packages, stores, and markets the fruit on behalf of its members and then pays members a share of the returns as the crop is sold.

Many growers of fruit and nut crops have experimented with marketing their own crops. Small quantities of fruit can be sold at farmers markets and flea markets or in mail-order businesses concentrating on the holiday market. Marketing large quantities requires considerable effort and firm contracts with retailers.

Quality standards are set and enforced by the Dried Plum Marketing Committee, the administrative body for the federal marketing order. Each year, the DPMC recommends a marketing policy to the U.S. Department of Agriculture, setting grade, size, and diversion limits, as well as other quality standards. 
The California Dried Plum Board administers industrywide promotion and research. The board conducts market research, contracts for product promotion, and allocates moneys for production and processing research.

The Prune Bargaining Association negotiates a field price with the processors each year and assists its members in marketing.

\section{WHERE TO GET MORE INFORMATION}

The University of California Cooperative Extension maintains offices in most counties with Farm Advisors who specialize in the crops that are grown in each area. We urge prospective growers to get information from UC before entering into commercial prune growing. The University also publishes several leaflets and books on farming practices, along with a free catalog, which are available at your local UC Cooperative Extension office or online at http://anrcatalog.ucdavis.edu.The California Dried Plum Board and the Federal Prune Marketing Committee have information about marketing and promotion along with sales data. They publish detailed statistical reports each year on tonnage, acreage, sizes, grades, shipment, usage, pack out, etc. Their shared address is P. O. Box 248180, Sacramento, CA 95854 (phone: (916) 565-6232; online at www.californiadriedplums.org).

The Prune Bargaining Association is located at 335 Teegarden Avenue, Yuba City, CA 95991 (phone: (530) 674-5636; online at www.prunebargaining.com).

\section{MORE INFORMATION FROM UC ANR}

You will find related information in these titles and in other publications, slide sets, CD-ROMs, and videos from UC ANR:

Integrated Pest Management for Stone Fruits, Publication 3389

Prune: UC IPM Pest Management Guidelines, Publication 3464

Seasonal Guide to Environmentally Responsible Pest Management in Prunes, Publication 21624

To order these products, visit our online catalog at http://anrcatalog.ucdavis.edu. You can also place orders by mail, phone, or FAX, or request a printed catalog of publications, slide sets, CD-ROMs, and videos from

University of California

Agriculture and Natural Resources

Communication Services

6701 San Pablo Avenue, 2nd Floor

Oakland, California 94608-1239

Telephone: (800) 994-8849 or (510) 642-2431

FAX: (510) 643-5470

E-mail inquiries: danrcs@ucdavis.edu

An electronic version of this publication is available on the ANR Communication Services Web site at http://anrcatalog.ucdavis.edu.

Publication 8264

ISBN-13: 978-1-60107-486-7

This publication has been anonymously peer reviewed for technical accuracy by University of California scientists and other qualified professionals. This review process was managed by the ANR Associate Editor for Pomology, Viticulture, and Subtropical Horticulture.

(C) 2007 by The Regents of the University of California Division of Agriculture and Natural Resources.

All rights reserved. 
The University of California prohibits discrimination or harassment of any person on the basis of race, color, national origin, religion, sex, gender identity, pregnancy (including childbirth, and medical conditions related to pregnancy or childbirth), physical or mental disability, medical condition (cancer-related or genetic characteristics), ancestry, marital status, age, sexual orientation, citizenship, or status as a covered veteran (covered veterans are special disabled veterans, recently separated veterans, Vietnam era veterans, or any other veterans who served on active duty during a war or in a campaign or expedition for which a campaign badge has been authorized) in any of its programs or activities.

University policy is intended to be consistent with the provisions of applicable State and Federal laws.

Inquiries regarding the University's nondiscrimination policies may be directed to the Affirmative Action/Staff Personnel Services Director, University of California, Agriculture and Natural Resources, 1111 Franklin Street, $6^{\text {th }}$ Floor, Oakland, CA 94607, (510) 987-0096. For information about obtaining this publication, call (800) 994-8849. For downloading information, call (530) 297-4445.

pr-10/07-WJC/CAM 